Italy

\title{
Confronting the Euro agencies
}

Vito Scalia, Italy's science minister, alerted Nature shortly before Christmas (see 20 December $\mathrm{p}$ 768) to the three-pronged attack he was to make on European research organisations. Speaking in the room in the Rome convent where Galileo was tried (right) Scalia demanded that Italy get fairer treatment from ESA, that CERN delay its decision on a new Director-General, and that the EEC adopt an experiment on nuclear reactor meltdown. The results of his efforts are now becoming plain, as Robert Walgate reports.

ITALY'S representatives at CERN, the European organisation for subnuclear research, withdrew from the 19 December Council meeting and refused to endorse the appointment of German Professor Herwig Schopper, as new Director-General from 1 January 1981.

The Italians are thus carrying out their threat to "consider seriously dissociating" Italy from CERN. One of the present joint CERN Directors-General, Dr John Adams, offered to visit Rome to mediate in the dispute - which is principally between Italy and Germany - but Rome refused.

The delegation is apparently still smarting from the rebuff it received - at a preliminary meeting - to its proposal that the future programmes of CERN should be "better clarified"' before an appointment is made. Italy fears that Germany is not altogether sincere in its commitment to CERN's future, as it is considering a proposal for an accelerator (HERA) that Italy believes is competitive with CERN's LEP (see page 5).

The Italian government has its own candidate for the CERN DirectorGeneralship, Professor Antonino Zichichi. But Italian scientists working at CERN were nervous of their delegation's tactics, as they rely on CERN and other non-Italian laboratories for their livelihood.

\section{JET under threat}

THE European Commission's Super Sara experiment on nuclear reactor meltdown is now supported by eight of the nine community members, with only France objecting.
At a meeting in Brussels of energy ministers of the nine, Italy - the strongest supporter of Super Sara - swung a number of other objectors (including Britain) behind her. But Pierre Aigrain, France's Minister of Science, continued to hold strong objections.

France claims that its similar experiment at Cadarache is more advanced than Super Sara - which would be conducted at the EEC Joint Research Centre at Ispra, north Italy, on an isolated circuit within the reactor ESSOR.

France's objections have led Italy to act on its threat to hold up once again the EEC's 1980-85 budget for energy research.

\section{ESA absorbs objections}

ITALY's attack on European research organisations succeeded in one respect: a tacit agreement of the Council of the European Space Agency to adjust the budget in Italy's favour to the tune of 27 million units of account (mua) (about $\$ 40$ million).

Italy had argued that it had lost some 32 mua over the allocation of contracts to build Spacelab, the orbiting laboratory which will be flown by the Space Shuttle.

The adjustments should be confirmed at a meeting on 23 January. They will come in the form of a reduced contribution over four years, and a greater allocation of Spacelab follow-on projects.

\section{United Kingdom}

\section{Government plumps for $P W R$ power station}

THE UK government has decided to embark on a major new nuclear programme. At least one nuclear power station is to be built each year during the decade beginning 1982 and the nuclear industry is to be revitalised to cope with the demands to be made of it. The estimated cost of the programme - to be paid for by the Central Electricity Generating Board - is $£ 10-12$ billion at 1979 prices. It is expected to increase the nuclear contribution to electricity supply from $12 \%$ to over $30 \%$ by the early 1990 s.

Mr David howell, Secretary of State for Energy, said when announcing the decision that the UK needed a nuclear programme of this size if it was to maintain the type of society it has now into the $1990 \mathrm{~s}$, when North Seal oil and gas production would decrease. The size of the programme, equivalent to about $15,000 \mathrm{MW}$, was based on Department of Energy forecasts of energy demand, assuming a $20 \%$ saving in consumption from conservation, he said.

A substantial programme was also needed to build up and maintain a strong industry; the lack of orders over the past decade had led to its decline. "If we are to reverse this trend and ensure that the industry is on a sound footing, we must act now", said Mr Howell. Under the reorganisation planned for the industry, the National Nuclear Corporation (NNC) and the Nuclear Power Company are to be brought under the umbrella of one board. The new NNC will then have total responsibility for management of all nuclear projects.

One of its first tasks will be the design of a pressurised water reactor under license from Westinghouse. In line with the previous Labour Government's decision, the Conservatives intend that the first power station of the programme will be a PWR. The design must be approved for safety by the Nuclear Installations Inspectorate and must be subject to a public inquiry. The NNC estimates that it could be ready for this by the end of 1981 , and that construction could begin in 1982 .

The NNC is also to assume responsibility for managing the UK's advanced gas cooled reactor (AGR) programme. By building two more AGRs as well as one PWR, the CEGB hopes that the final choice of reactor can be left for some time. However Mr Howell has said that a commitment to one system or the other would have to be made fairly early on in the programme.

The major advantage of the PWR over the AGR is capital cost. The CEGB estimates that the capital cost per MW is $£ 750,000$ for an AGR and $£ 680,000$ for a PWR.

- The British nuclear industry and the NII have released preliminary statements on the implications of the accident at Three Mile Island. They conclude that the recommendations of the President's commission, set up to investigate the accident, do not apply to the UK. Fault was found with the regulatory procedure in the US and the standard of operator training but not with the basic PWR design. Most of the suggestions for improvement, they say, are already incorporated in the UK regulatory procedure.

Judy Redfearn 